\title{
Zimbabwe in Creative Imagination: Environmental Crisis and Human Migration as National Tragedies in Shimmer Chinodya's Dew in the Morning
}

\author{
Chukwu Romanus Nwoma ${ }^{1}$ \\ Department of English and Literary Studies, Alex Ekwueme Federal University, \\ Ebonyi State, Nigeria \\ Onyekachi Eni \\ Department of English and Literary Studies, Alex Ekwueme Federal University, \\ Ebonyi State, Nigeria
}

\section{Abstract}

This study examines the representation of Zimbabwe's environmental history, with a focus on the tragic interface between environmental crisis and human migration, in Shimmer Chinodya's novel Dew in the Morning. The paper reveals the interconnectedness between literature and the environment. It demonstrates the creative reflection on Zimbabwe's environmental crisis, the burden on land, and human displacement. Migrant ecocriticism as the theoretical framework of the study aids in interrogating the intersection and mainstreaming of environmental crisis and social displacement in the novel. The discovery is that rising human population, adverse technological forces, and unbridled economic considerations accelerate the degradation of the environment and result in ecological disturbances which induce human migration. The novel's characters are circumscribed in a web woven by their actions and inactions as their depressing circumstances reflect the degree to which they exploit the environment. These contending realities provoke environmental crises and social tensions which precipitate human migration.

Keywords: African literature, Dew in the Morning, environmental crisis, human migration, migrant ecocriticism, Shimmer Chinodya

Recommended citation (APA 7th ed.)

Nwoma, C. R., \& Eni, O. (2021). Zimbabwe in creative imagination: Environmental crisis and human migration as national tragedies in Shimmer Chinodya's Dew in the Morning. Human Ecology Review, 27(1), 125-137. doi.org/10.22459/HER.27.01.2021.07

1 Corresponding author: nwomaromanus@gmail.com. 


\section{Introduction}

The past six decades have witnessed a gradual increase in African narratives that represent environmental crisis. African creative writers have steadily and inevitably represented Africa's environmental history with a view to weaving narratives that are commentaries on the African environment. There have been representations of how human beings negatively alter the environment in most unimaginable ways. Such representations are markedly dissonant with what has been considered colonial representation of the African environment. Catejan Iheka's African Literature and the Environment: A Study in Postcolonial Ecocriticism holds that "in colonial writing on Africa, the African environment was portrayed as being in a pure state of nature" (2015, p. 8). Such representations may be valid only within the periods in which they were crafted. Contemporary African realities attest to the fact that the African environment is no longer in "a pure state of nature," as may only be found in the realm of utopia. From the days of Chinua Achebe, Bessie Head, Isidore Okpewho, Shimmer Chinodya, and so on-the earliest African writers to address the environment in their creative works-different environmental crises have been represented in African narrative fiction, ranging from the actual to the hypothetical. Contemporary African authors have increasingly shown interest in environmental sustainability as Africa is constantly challenged by emerging environmental crises such as drought, desertification, flood, global warming, acid rain, pandemics, and so on.

Shimmer Chinodya's novel Dew in the Morning (1982/2001) is one such narrative, and was written against the backdrop of Zimbabwe's colonial history, when land was a factor that often ignited social tensions. Zimbabwe was then known as Rhodesia and was in the grip of a white minority. Although the novel was first published in 1982, two years after the independence of Zimbabwe, it was written earlier, before Zimbabwe's independence. Shimmer Chinodya represents in the novel the burden on land, environmental crisis, and the subsisting social tensions. The struggle for and partitioning of land results in its excessive exploitation and consequent degradation. Technological incursion and increasing industrial activity worsen the climatic challenges the characters battle with. Chinodya reimagines space where the characters determine the future of their environment through their actions and inactions. He weaves an apocalyptic vision of a countryside where the inhabitants battle implacable natural forces.

Critics have focused on different issues in Chinodya's novel but there has been no critical focus on environmental crisis as a precursor to human migration, the tragic interface between environmental decline and social displacement. Writing on "Childhood, Space and Belonging: Shimmer Chinodyas Dew in the Morning," Robert Muponde (2004) observes: 
the story is told from the point of view of a young boy called Godi ... from the time when he is 8 to about the time when he turns 17 . His family relocates from the city to a rural area under the headmanship of Jairosi, a corrupt and bribe-seeking ne'erdo-well. (p. 77)

Muponde concludes that "many other families are also moving into headman Jairosi's area, but the reasons for this mass migration are not explored" (2004, p. 77). To consolidate his assertion, Muponde draws on Rino Zhuwarara's (1987) similar view on Chinodya's Dew in the Morning (Muponde, 2004, p. 77):

But if one expects Chinodya to explore the forces which have brought about a situation which separates members of the same family, or the reasons why families keep on moving to new areas to settle, one is bound to be disappointed. Chinodya's passion as an artist lies in the rhythms of rural life as they change in line with the tropical seasons. (Zhuwarara, 1987, p. 134)

This study disagrees with Muponde's position that Chinodya did not explore the reasons for the mass migration. The reasons for the mass migration in Dew in the Morning constitute the thrust of this study.

Migration could not have happened out of nothing; migration is largely a reaction, a response to stimulus. The forces that stimulate migration are not lacking in Dew in the Morning. Rather, it is the novel's characters who appear to lack the critical lens to recognize the forces that provoke their migration.

Maurice Taonezvi Vambe (2007), writing on the representation of race and land ownership in Dew in the Morning, concludes that his paper

analyses Shimmer Chinodya's novel Dew in the Morning in order to demonstrate that fiction has the capacity to reveal patterns of meaning that comment on race relations and to show how these are related to the issue of land ownership in Rhodesia. (p. 257)

He further says that "Dew in the Morning recounts different kinds of resistances that emphasise [sic] the 'peasant option'” (Vambe, 2007, p. 257). Vambe's critical focus centers on race relations, land ownership, and resistance, which obviously were subsisting issues in colonial Rhodesia, and which Chinodya also explored in the novel. The different critical views on Dew in the Morning have approached the novel through dimensions other than the dimension of the current study.

The novel is set within the context of fictional Zimbabwe and narrated by a very young narrator named Godi. Through Godi's various accounts, it is revealed that the southern environment has been excessively exploited, a condition that has induced environmental reactions. The north is largely in its natural state, as it has not been opened up to mindless exploitation. The forests are still thick, a habitat that encourages the growth of species already extinct in the south. The government finds the north a place of refuge for the characters as it encourages them to give the tumultuous 
south some respite by moving to the north. The north accepts the newcomers but the presence of these newcomers constitutes a great threat to its environment. The derukas ("settlers"), as the newcomers are called, continue with similar activities that destroyed the south, and there is a noticeable environmental decline shortly after their migration. Chinodya's narrative portrays tragic consequences of environmental decline of a monumental proportion and regional migration within a sovereign state, and demonstrates the capacity of narrative fiction to weave a discourse on environmental crisis. He envisions and reimagines the future of space within that fictional universe, and gives the reader an apocalyptic vision of environmental crises and human responses.

Drawing from the theoretical approach of migrant ecocriticism, this study examines Chinodya's representation of environmental crisis as a precursor to human migration.

\section{Ecocriticism}

This study is ecocritical in orientation; it is an examination of the intersection between literature and the environment. Ecocriticism is a product of the late twentieth-century environmental activism that seeks to give prominence to environmentalist principles through the medium of literature. It moves away from the eighteenth-century romantic idealization of the environment and adopts a revolutionary approach in its interrogation of the relationship between literature and the environment. As a theory, it came into the limelight in 1996 with the publication of The Ecocriticism Reader: Landmarks in Literary Ecology, edited by Cheryll Glotfelty and Harold Fromm. Ecocriticism has been defined as "the study of the relationship between literature and the physical environment" (Glotfelty 1996, p. xviii). Glotfelty's conceptual grasp and foundational definition of ecocriticism opened a floodgate of critical strands that manifest a multiplicity of views on this theory. These views embody the diverse ideological and thematic preoccupations which literature explores. There are such strands as migrant ecocriticism, ecofeminism, environmental justice ecocriticism, postcolonial ecocriticism, and so on. Glotfelty acknowledges the possibility of these multiple strands when she says that "in the future we can expect to see ecocritical scholarship becoming ever more interdisciplinary, multicultural and international" (1996, p. xxv). A common denominator among all the strands is their focus on the interconnection between literature and the environment. This focus places literature in a multidisciplinary perspective and aligns with Akwanya's observation that "literature is even more expansive, entering every domain, and carrying away materials for new constructions" (1997, p. 47). The theoretical underpinning of this study is a strand of ecocriticism called migrant ecocriticism. Migrant ecocriticism is one of the manifestations of Glotfelty's prophetic projections about ecocriticism. 
Rina Garcia Chua conceptualized migrant ecocriticism and holds that, "in this developing project, I am interested to explore the intersections of postcolonial ecocriticism, diaspora studies, and transnationalism to expound on the possibilities of a Migrant Ecocriticism" (2019, p. 211). Chua advances fundamental questions migrant ecocriticism can address. She asserts thus:

The questions that a Migrant Ecocriticism may scout and identify are these: How is space reimagined by the multiple conceptions of a migrant, social, biological, and socio-ecological? Is it constructed out of a shared consciousness-an alliance with the different cultures encountered within the journeys undertaken? Is it a coping mechanism-defensive or not—created to find one's self in another foreign space? Or may it be a method that can attempt to transcend borders within and outside cultures? (p. 211)

Space is the heart of Chua's concept of migrant ecocriticism as can be deduced from the foregoing questions. She appears to be deeply interested in the dispositions and responses of the migrant in relation to space in which they find themselves; the interpretive lenses that aid the migrant to visualize space in some concrete terms. Chua further maintains:

in Migrant Ecocriticism, there has to be an understanding of how migration has either made or broken the migrant, and how migration has either deterritorialized or reterritorialized the space the migrant occupies-for better or worse, to sift through the apprehension. (Chua, 2019, p. 216)

Chua's use of the terms "deterritorialized" and "reterritorialized" consolidates and further undergirds space as the central focus of migrant ecocriticism.

Migrant ecocriticism is most appropriate for this study as it espouses the representation of space and also how narratives envision the future of space. It offers itself for explications of narratives with apocalyptic visions of space, visions of tumultuous environments where migration is implicated in the devastating consequences of a degraded environment. Julie Bertagna's novel Exodus (2002) is an example of a narrative with an apocalyptic vision of the future, where the currents of ecological disasters are too strong for the characters to contend with, resulting in social dislocation and forced migration. This study will use migrant ecocriticism to interrogate the representation of place and displacement.

\section{Conceptual framework}

This study is reinforced by the following two working concepts that also serve as critical tools: "environmental crisis" and "human migration." These concepts will be briefly explored in the light of this study. The Dictionary of Environment and Conservation conceptualizes environmental crisis as: 
A term that is used to describe the sum of the environmental problems that we face today. Key contemporary environmental problems include the greenhouse effect and global warming, the hole in the ozone layer, acid rain, and tropical forest clearance ... A number of factors have helped to create these problems, including developments in technology, which have given people a greater ability to use the environment and its natural resources for their own ends (particularly since the Industrial Revolution); the rapid increase in human population in recent centuries, which has significantly increased population densities in many countries and led to a significant rise in human use of natural resources. (Oxford Reference, n.d.)

Environmental crisis affects the entire environment, which "encompasses all natural and artificial nature, including the cultural goods related" (Silva et al., 2013, p. 3). The disturbance of both the biotic organisms and the abiotic factors within an existential space is implicated in the concept of environmental crisis. It also recognizes the privation of all species and their habitats. Environmental crisis is used in this study as an encompassing term for the destabilization of the natural balance of the biotic components (living things) and the abiotic components (non-living things) of the environment.

The International Organization for Migration (IOM) offered a definition that provided a robust account of the concept of human migration. According to the IOM (as cited in Chua 2019, p. 214), human migration is conceptualized as

the movement of a person or a group of persons, either across an international border, or within a state. It is a population movement, encompassing any kind of movement of people, whatever its length, composition and causes; it includes migration of refugees, displaced persons, economic migrants, and persons moving for other purposes, including family reunification.

The IOM's definition of human migration encompasses the range of conceivable circumstances that may provoke human migration. It is a commonplace phenomenon in Africa as the wheels that keep it rolling are lubricated by diverse and complex factors across the African continent. The discourse on human migration is expansive and multidisciplinary; many disciplines in the social sciences and the humanities participate in this discourse. Human migration has been variously represented in literature; Dew in the Morning is one such representation. Wang and Tötösy de Zepetnek (2010) hold that "culture and cultural expressions including literature and art contain many examples of life experiences related to migration and diaspora" (p. 2). Shimmer Chinodya has woven into his plot structure migration that is provoked by environmental crisis. Economic considerations induce the characters to degrade their immediate environment and they are forced by the tragic consequences to migrate to a better and safer environment. The foregoing interlocking concepts, "environmental crisis" and "human migration," are interpreted in this study as tragic phenomena because of their subsisting negative force in the novel. The concepts reinforce this study's explication of the novel. 


\section{Interrogating the text: Environmental crisis and human suffering}

Chinodya's narrative reflects on the burden on land, environmental privation, and human suffering as a result of unbridled economic forces. Deforestation, overgrazing, bush burning, and other forms of environmental degradation have altered the different components of the environment. Acts of destruction of the environment are rife in the text. Chinodya reimagines the apocalyptic future of Zimbabwe's social space where environmental decline is a national phenomenon within the imagined Zimbabwe. The characters suffer horrible conditions in a landscape ravaged by drought and pollution ("black smoke oozed persistently out of the factory chimneys" [p. 17]). The presence of factories is evidence that the country is industrialized to some extent, and the narrative implies that the industries pollute without restraint. And yet, despite the horrors they face, the people never give a thought to the causes of their problems and never think about remedies. Rather, their actions worsen the already dire situation.

The south has been deserted by most people, especially farmers, because the land is degraded and no longer supports agriculture, a situation that constantly echoes forced displacement and deterritorialization. This undoubtedly results in a lopsided existence in the social formation of the south. The conditions that induce the migration of the characters is in tandem with Bryne's (2018) observation that "environmental migration is often motivated by insuperable, adverse circumstances rather than desire or individual autonomy" (p. 766). This follows Brown's (2008) opinion that "migration is (and always has been) an important mechanism to deal with climate stress" (p. 14). The north is comparatively less developed than the south and the inhabitants are at peace with the natural environment because they have not excessively exploited it. The south is developed in terms of basic amenities, but it is faced with serious environmental challenges that have become persistent and adversely affect the farmers. Migration becomes the last option that would help to avert the anger of the ravaging and tumultuous environment. Godi, the narrator, paints a portrait of the collapsing environment and the characters' responses to the situation. He observes that:

In the southern regions of the country, the drought had been acute ... Because it was a densely populated region, fields were small and the soil old and overworked. Most of the trees had been cut down for wood and the land lay in aching nakedness, raped by the plough and the axe ... At last it was decided to move people into the remote virgin land in the north to give the denuded region a chance to become green again. At first, there was opposition to this plan by the villagers but eventually, after much persuasion, they agreed to destroy their homes, leave their deceased kin's graves and their fatherland and move into the new land. (Chinodya, 1982/2001, p. 29) 
Godi graphically depicts the state of the southern part of the country that leaves the people with no options but migration. The land has been completely destroyed and the climate system of the region altered. The initial resistance to migration does not arise from doubts about a better future but from the considerable deprivations they will suffer in abandoning their homes and their heritage-a case of deterritorialization.

Thoughts of migration elicit in the characters a sense of ambivalence; of certainties and uncertainties. These mixed feelings are what the characters contend with as they gradually overcome their fears. Such fears are in the thoughts of Pourjafari and Vahidpour (2014) when they argue that "a common feature of many of migrant writing $[s i c]$, therefore, is ambivalence" (p. 688). Chinodya illustrates a limit to resistance and also a limit to ambivalence and human endurance-for the characters, resistance and ambivalence give way when the situation becomes unendurable. Migration becomes the only option for the regeneration and renewal of the ecology of the south and the hopes of its residents. The narrator observes the migration of the characters to the north:

Towards the end of July, during the middle of the cold dry season, when roads were negotiable, the movement from the south started. Families came in convoys of closely packed government lorries, taking two or three days to complete the journey, so that passengers frequently camped out for the night. (Chinodya, 1982/2001, p. 30)

The above episode creates dual and contrasting images: of catastrophe and of refuge, of dislocation and of relocation, of deterritorialization and of reterritorializationof the environment's capacity to harm and to save. The south is torn apart by catastrophes while the north offers itself as a place of refuge. The phrase, "to give the denuded region a chance to become green again" (Chinodya, 1982/2001, p. 29) shows a measure of environmental awakening and consciousness on the part of the government, a triumph for ecocriticism: "Ecocriticism concurs with other branches of the environmental humanities — ethics, history, religious studies, anthropology, humanistic geography-in holding that environmental phenomena must be comprehended, and that today's burgeoning array of environmental concerns must be addressed qualitatively as well as quantitatively" (Buell et al., 2011, p. 418). Although this ecological consciousness that negotiates environmental sustainability is not evident in the actions of the characters, the government has displayed some measure of commitment to redressing the troubling trajectory that has resulted in environmental crisis in the south. 


\section{Diaspora and the migrants' experience}

The portraits of the migrants revolve around the frame of displacement. Although the north offers them a place, there are still feelings of dislocation and dispossession. The dispositions of the northerners toward these migrants often impede the efforts of the migrants to be properly integrated into the strange land. The north offers them a place that fails to elicit in them a sense of home. The northerners use the term derukas - "settlers" - to address the migrant southerners. The alienating implication of derukas induces what Pourjafari and Vahidpour call "shifting identities" (2014, p. 679). The migrants have inadvertently acquired a new identity; an identity that constantly reminds them of their status as outsiders. The experiences of the migrants in the north address the question migrant ecocriticism raises: "How is space reimagined by the multiple conceptions of a migrant ... ?” (Chua, 2019, p. 211). The derukas exist on a social periphery within the context of the north, assuming the status of a marginal group, a group Timothy Smith views as "those who lived on the margins of rural society, with no firm roots or legal claims to the land" (Smith, n.d., "Rural Marginals" section). It is possible that such a hurtful existential status and identity partially impels the destruction of the northern environment by the migrants, but it is also possible that the destruction of the environment of the north is the evidence that the derukas have learnt no lessons from their previous experiences that induced their social dislocation in the south.

The consequences of accommodating the derukas are as traumatic as they are troubling. The northerners do not fully grasp the condition of the south, or perhaps they are unaware of the factors that led to that condition. The derukas export their culture of deforestation and other forms of environmental degradation to the north. In Chinodya's narration, a distraught Godi unleashes graphic descriptions that evoke images of desolation, using such terms as "destroyed," "the great trunks sprawled on the ground," "dry brown leaves clinging to the withered twigs," "yellow chips littering the perimeter of the tree-stumps," and so on (1982/2001, p. 13), to describe his observation of the mournful state of the northern forests. Godi's linguistic choices are potent narrative tools as they convey the depth of human actions against the environment. His narrative perspective advances the preponderance of evidence that the environment suffers privation in the text, from the south to the north. The young narrator as a member of the rustic and peasant community has a deep understanding of the realities of his milieu. There may be other linguistic terms available to him but he chooses to use terms that evoke the harm to the environment. One could possibly argue that the north is an agrarian society; therefore, certain practices that inadvertently affect the environment are expected-but the position of the narrator eclipses that line of thought. He sees these actions as destructions rather 
than normal actions that are part of their culture. Godi is represented as a symbol of environmental consciousness, a character Chinodya frames as the conscience of Zimbabwe.

The despoliation of the hitherto pristine enclave is enormous as the derukas ceaselessly plunder the environment of the north. The cumulative negative effects are imminent. There are signs of impending environmental crisis in the north. Godi describes the changes:

Life had changed in the village. Jairos had had an easy time as headman: the village was young, the forests wild, human wounds healed as easily as new foliage grew on trees. Now the forests were gone and people had become restless. The owls did not hoot any more. The huge trees where they had perched had been cut down for firewood. Ten years previous, owls had been part of the village, but now when an owl hooted people woke up with throbbing hearts, to listen ... it was the reign of the axe and the goats, the axe which opened the forests to the ravishing plough, and the goats, which mushroomed in number and were rarely killed for meat. (Chinodya, 1982/2001, p. 139)

The change that has taken place is a rapid one. Within just 10 years the forests are gone and the people are restless because of the effects. The natural ambience of the village is lost to the exploitative proclivities of the newcomers as the closeness of humans to nature is substantially vitiated. Species like the owls that used to be part of the village and hoot around the trees have become harbingers of doom. Their presence has become a source of anxiety. Snakes that are historically connected to the villages have also gone into extinction, even the ones the people adore. The predisposition of the derukas to indiscriminate deforestation and bush burning is destroying the habitats of these species.

\section{Reinventing the debased environment}

Technological interventions are framed as part of the conscious efforts directed toward the resolution of environmental crisis in the text. Chinodya's account of the use of mechanization to revive farmland in the denuded ecology of the south is very profound in the text: The narrator observes that "although people there used tractors and fertilizers, and took advice from local agricultural demonstrators, farming was bad" (1982/2001, p. 29). This is an effort by Chinodya to portray the extremity of the collapse of the ecology of the south; a collapse of unimaginable proportion. The failure of mechanization to resolve the crisis pushes the government into further research on how to renew the devastated ecology of the south. The discovery of a solution leads to the policy of forced migration, to move the people out of the uninhabitable south and into the lush north "to give the denuded region a chance to become green 
again” (p. 29). Here we see Chinodya's firm belief in ecological renewal-a vision of hope. The process of achieving this renewal is long and cumbersome, a process that involves social dislocation of the characters-a retribution for recklessness.

Chinodya's narrative is a commentary on the importance of interdependence; a recognition of the relevance of the different components of the environment. Based on the principle of interdependence, the anthropologist, Rose, holds that:

The new ecology starts with this fundamental assertion that the unit of survival is not the individuals or the species, but is the organism-and-its-environment in relationship. It follows from this that an organism that deteriorates its environment commits suicide. (2004, p. 188)

The southerners have lived as though they are absolutely independent of other natural components of their environment, without the realization that their survival is dependent on a relationship of interconnectedness with these vital components. The characters pay a huge price for overlooking this principle and also for not recognizing that "a perfect ecology is one in which plants, animals, birds and human beings live in such harmony that none dominates or destroys the other" (Frederick, 2012, p. 147).

\section{Conclusion}

Shimmer Chinodya creates in Dew in the Morning a structural trend that echoes human actions and environmental reactions, where environmental reactions irredeemably provoke human migration. The characters are circumscribed in a web woven by their actions and inactions as their depressing circumstances reflect the degree to which they have exploited the environment. The characters who are victims of forced migration and social dislocation are neither circumspect in their interactions with the environment nor have any realization that they are victims of their own actions. The reckless exploitation of the environment has consequences which are an eternal burden on them but it is also indelibly inscribed in them: Exploitation is a part of them wherever they go. Their failure to recognize that they are in a reciprocal relationship with the environment denies them what Frederick (2012) calls "the modern ecological consciousness ... a feeling that the balance between human and the natural world must be maintained" (p. 147), and what Mishra (2016) sees as "sustainable development for a better future of mankind in general" (p. 168), which she argues is one of the principles ecocriticism advocates for.

The corollary of the foregoing is that Frederick's (2012) and Mishra's (2016) ideological underpinnings on ecocriticism intersperse this study and reinforce the ecocritical methodology in interrogating the representation of Zimbabwe's environment in narrative fiction. The discovery is that, in the reimagining of space 
in the narrative, spatial distribution and redistribution of the human population are serious environmental concerns. Also, environmental crisis and human migration constitute tragedies of national note. The analyses address migrant ecocriticism's question of "how is space reimagined by the multiple conceptions of a migrant, social, biological, and socio-ecological?" (Chua, 2019, p. 211). The trajectory and phases of Zimbabwe's environmental history are revealed through a fictional construct, and are accounted for through the ecocritical methodology, and most effectively through the strand of migrant ecocriticism. This paper reinforces the fundamental principle of ecocriticism which is the study of the relationship between literature and the environment. The interdisciplinary approach of the study is ecocriticism's badge of identity.

\section{References}

Akwanya, A. N. (1997). Verbal structures. Acena Publishers.

Bertagna, J. (2002). Exodus. Young Picador.

Brown, O. (2008). Climate change and forced migration: Observations, projections and implications [Occasional paper] (Human development report 2007/2008). Human Development Report Office, United Nations Development Programme. hdr.undp.org/ en/content/climate-change-and-forced-migration

Bryne, C. (2018). Climate change and human migration. UC Irvine Law Review, 8(4), 761-788. scholarship.law.uci.edu/ucilr/vol8/iss $4 / 6$

Buell, L., Heise, U. K., \& Thornber, K. (2011). Literature and environment. The Annual Review of Environment and Resources. 36, 417-440. doi.org/10.1146/annurevenviron-111109-144855

Chinodya, S. (2001). Dew in the morning. Heinemann Educational Publishers. (Original work published 1982).

Chua, R. G. (2019). Toward a migrant ecocriticism. In T. Ong \& I. Lacuna (Eds.), Látag: Essays on Philippine literature, culture, and the environment, (pp. 207-222). University of the Philippines Institute of Creative Writing. www.academia.edu/39631759/Toward_a_ Migrant_Ecocriticism

Frederick, S. (2012). Contemporary contemplation on ecoliterature. Authorpress.

Glotfelty, C. (1996). Introduction: Literary studies in an age of environmental crisis. In C. Glotfelty \& H. Fromm (Eds.), The ecocriticism reader: Landmarks in literary ecology (pp. xv-xxxvii). University of Georgia Press.

Iheka, C. N. (2015). African literature and the environment: A study in postcolonial ecocriticism [Unpublished doctoral thesis]. Michigan State University. 
Mishra, S. K. (2016). Ecocriticism: A study of environmental issues in literature. BRICS Journal of Educational Research, 6(4), 168-170. www.bricsjer.com/index.php/brics/article/ view/176

Muponde, R. (2004). Childhood, space and belonging: Shimmer Chinodya's Dew in the morning. African Identities, 2(1), 77-88. doi.org/10.1080/1472584042000231782

Oxford Reference. (n.d.). Environmental crisis. In A dictionary of environment and conservation. Retrieved May 15, 2020, from www.oxfordreference.com/view/10.1093/oi/authority. 20110803095753543

Pourjafari, F., \& Vahidpour, A. (2014). Migration literature: A theoretical perspective. The Dawn Journal, 3(1), 679-692. www.thedawnjournal.in/dj-vol-3-no-1-januaryjune-2014/

Rose, D. B. (2004). Reports from a wild country: Ethics for decolonization. University of New South Wales Press.

Silva, J., Iluska, B., João, M., Filho, P., de São, F., \& Francisca, O. (2013). Critical analysis on the environment concepts. Review of Research, 3(3), 1-14.

Smith, T. B. (n.d.). Marginal People. In Encyclopedia of European social history. Retrieved September 3, 2019, from www.encyclopedia.com/international/encyclopedias-almanacstranscripts-and-maps/marginal-people

Vambe, M. T. (2007). Race and land ownership in Rhodesia: Trajectories of conflicting nationalisms in Shimmer Chinodya's Dew in the Morning. Development Southern Africa, 24(2), 257-270. doi.org/10.1080/03768350701327160

Wang, I-C., \& Tötösy de Zepetnek, S. (2010). Introduction. In S. Tötösy de Zepetnek, I. Wang, \& H.-Y. Sun (Eds.), Perspectives on identity, migration, and displacement (pp. 2-3). Center for the Humanities and Social Sciences and the College of Liberal Arts, National Sun Yat-Sen University.

Zhuwarara, R. (1987). Zimbabwean fiction in English: Essay review. Zambezia, 14(2), 131148. hdl.handle.net/10520/AJA03790622_457 
This text is taken from Human Ecology Review, Volume 27, Number 1, 2021, published by ANU Press, The Australian National University, Canberra, Australia.

doi.org/10.22459/HER.27.01.2021.07 